\title{
Investigating the Performance of Ilami EFL Teachers in Observing the English Intonational Patterns Based on Their Gender
}

\author{
Malihe Rajabi \\ Department of English Language Teaching, Islamic Azad University, Ilam Branch \\ Pajouhesh Boulevard, Ilam, Iran \\ Habib Gowhary (Corresponding author) \\ Department of English Language Teaching, Islamic Azad University, Ilam Branch \\ PO box 6931696876, Pajouhesh Boulevard, Ilam, Iran \\ E-mail: h gowgary@yahoo.com \\ Akbar Azizifar \\ Department of English Language Teaching, Islamic Azad University, Ilam Branch \\ Pajouhesh Boulevard, Ilam, Iran
}

Doi:10.7575/aiac.alls.v.6n.2p.242

URL: http://dx.doi.org/10.7575/aiac.alls.v.6n.2p. 242
Received: 20/12/2014

Accepted: 23/02/2015

\begin{abstract}
The current study extracted, first, 17 general patterns of intonation. Additionally, the present study investigated the roles that might be played by the gender of Ilami EFL teachers in observing the 17 patterns of intonation. Finally, the study determined if intonation as a suprasegmental feature of speech is affected by the gender of Ilami EFL teachers. The population of the study encompassed all male and female EFL teachers in Ilam city from which 40 teachers (20 males and 20 females) were surveyed on interviews for their observing of 17 general patterns of intonation. For inferential statistics, Chi-Square tests were conducted to analyze the data. Statistical analysis was run using Statistical Package for Social Sciences (SPSS). Accordingly, male teachers outperformed female teachers on observing the rules of intonation.
\end{abstract}

Keywords: Suprasegmental aspects of speech, Intonation, EFL teachers

\section{Introduction}

According to Yates (2013)" Pronunciation, once a mainstay of language teaching and language teacher education has long been ignored or relegated to elective status in EFL classroom and pronunciation is rarely incorporated into instructional objectives, and when it is taught is usually done so in an ad hoc fashion." However, considering the overarching role played by pronunciation in speech intelligibility, the need for practical training in teaching pronunciation is inevitable.

In today's interconnected world, knowing English has been one of the inevitable parts of our lives. We judge people by the way they speak, consequently learners with good pronunciation may be judged competent, educated or knowledgeable. A broad definition of Pronunciation includes attention to particular sounds of language (segments) and the aspects of speech beyond the level of the individual sounds, (suprasegmentals) such as intonation, stress, phrasing, timing, rhythm suprasegmental aspects of language which are best learned as an integral part of language.

Traditional approaches to pronunciation have often focused on segmental phonemes, as they are relate in some way to letters in writing. More recent approaches to pronunciation suggested that suprasegmental aspects of pronunciation may have the most effect on intelligibility for some speakers. Usually learners benefit from attention to both aspects. Baily (2003) stated that Suprasegmental or prosodic speech characteristics carry meaning differences but they operate "above" the segmental phonemes.

Renewed interest in pronunciation in communicative approach focuses on phonological aspects of connected speech. This integrated approach to pronunciation teaching focuses on suprasegmental aspects of phonology. In fact it is the suprasegmental features that control the structure of information. The misuse or under-use of these features can cause the utterance to be understood in a way other than was intended, and can cause frustration, and possibly demotivation, from among prosodic features intonation is not only central to conveying meaning but attitude as well .Therefore, students must understand the function of intonation in conveying attitude (Avery \& Ehrlich 1992).

As failure in understanding a foreign language learner can be ascribed to poor pronunciation, a frustrating and unpleasant conversation can be a corollary to the poor prosodic and intonational skills (Ineke Mennen 2006). "Prosody provides the framework for utterances and directs the listener's attention to information the speaker regards as 
important." (Anderson- Hesieh 1992, as quoted in Jahandar et al. 2012). According to Laroy (1995) it is impossible to speak without rhythm and intonation, and these deeply affect the quality of speech sounds. All in all intonation conveys a variety of information including a grammatical structure, information structure of an utterance, discourse function and attitude and regulating turn- taking in conversation in social interaction ( Nolan 2006 ). Speech acts and styles are influenced by demographic backgrounds such as age, gender and ethnicity. Gender patterns in language have led to division of male /female speech community and thus intonation is not excluded from this. Brend (1975) pointed that male and female have different performance in the use of intonation patterns. Also Lakoff (2004) stated that American women in conjunction with declarative use more question intonation to show their politeness and cooperation.

Given that the studies on the effect of gender on intonation variation are scarce, or mostly employ contrastive analysis, the current study aimed at investigating the effect of gender on the music of language i.e. intonation. In order to investigate the relationship between the gender of Ilami EFL teachers and their observing of intonational patterns a short corpus of topically unrelated sentences was designed and all the forty teachers in the study were asked to read it to check their observing of the intonational patterns in American English.

\subsection{Supra Segmental Aspects of Speech}

Sound phenomena as accent and intonation may stretch over more than one segment. (Richard et al. 1992). Suprasegmental aspects (prosody) are stress, rhythm, and intonation that play an important role in comprehension and production of the language (Brazil et al.; 1980; Debot and Mailfert, Munro and Derwing 1982).

\subsection{Intonation patterns}

Intonation refers to patterns in the spoken form of language which are usually expressed by variation in pitch, loudness, syllable length, and sometimes speech rhythm (Richard 1992).

\subsection{EFL Teachers}

According to Celce- Murica (2001) teachers of English as a foreign language are non native speakers of English and are expected to serve as the major model and source of input in English for their students whose oral communication needs mandate a high level of intelligibility and therefore requires special assistance with pronunciation.

\section{Method}

\subsection{Participants and procedures}

The accessible population for the current study included all male and female English language teachers in Ilam city. Forty Ilami EFL teachers (twenty male and twenty female teachers) with different teaching experience and degree levels were randomly selected. Participants who attended the interview were high school English teachers and English language instructors working in institutes.

\subsection{Instrument}

The participants in the study were asked to read 17 topically unrelated sentences containing 17 patterns of intonation in American English extracted from Yavas (2006). Sentence reading was utilized to ensure that all relevant phonological contexts were included in the corpus. The sentences were carrying different intonation patterns. In order to avoid pauses between the target word and the word preceding or following it, the participants were asked to reread the sentence whenever there was hesitation. Participants were asked to read the data orally to see if $\mathrm{s} / \mathrm{he}$ observes the rules or not. This was done for each participant separately.

\subsection{Data analysis}

The current study employed 17 intonation patterns of English language. The patterns were extracted from valid sources. For each participant a mark was recorded by ticking yes or no for each item read by the participant. To analyze the data, the software SPSS (Statistical Packages of the Social Sciences) was run.

\section{Results}

\subsection{Demographics of participants}

The current study encompassed 40 (20 male and 20 female) EFL teachers who are teaching at high schools and institutions in Ilam city. Table 1 displays the descriptive statistics regarding the number and distribution of Ilami EFL teachers' and their performance in observing/not observing the rules for intonation patterns.

Table 1. The number and distribution of the participants based on observing intonation rules

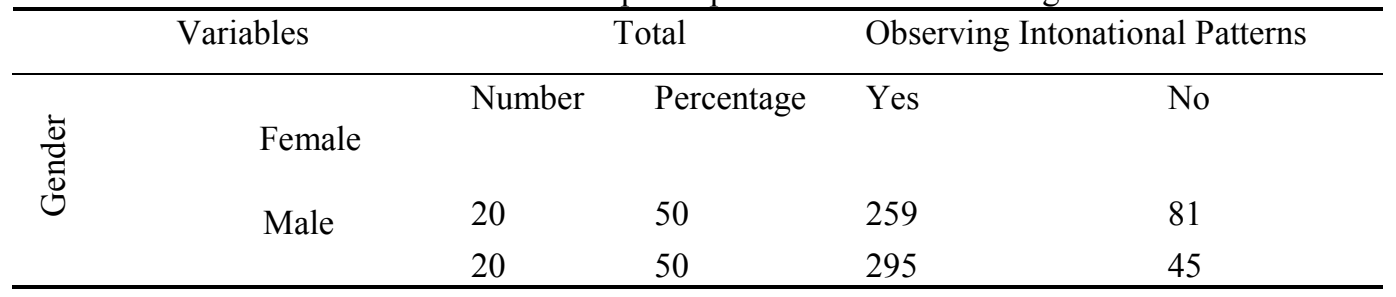


As illustrated in table 1, the number of male/female participants who observed the rules for intonation was recorded as 295, 259 respectively. This shows that the male participants out performed female participant in observing patterns of intonation in American English.

\section{Investigating research questions and hypotheses}

The research question and its related hypothesis developed in the current study are presented as it follows.

Research Question: Is there any relationship between the gender of Ilami EFL teachers and their observing of intonational patters?

Research Hypothesis: There is no relationship between the gender of Ilami EFL teachers and their observing of intonational patters.

Table 2 summarizes the cross-tabulation results of the participants' gender and their observing of intonation rules.

Table 2. Gender-Intonation Cross tabulation

\begin{tabular}{|c|c|c|c|c|}
\hline & & \multicolumn{2}{|c|}{ Gender } & \multirow{2}{*}{ Total } \\
\hline & & Female & Male & \\
\hline Observing intonational patterns & Yes & 259 & 295 & 554 \\
\hline Total & & 340 & 340 & 680 \\
\hline
\end{tabular}

The number of the female participants who did/did not observe the intonation patterns of American English was recorded as 259 and 81 respectively. The number of male participants who did/did not observe intonation rules was divided as 295 and 45 respectively.

Table 3 illustrates the finding on the relationship between the gender of Ilami EFL teachers and their performance regarding the rules of intonation.

Table 3. The results of Chi-Square Tests for the gender of Ilami EFL teachers and intonational patterns

\begin{tabular}{cccccc}
\hline & Value & $\begin{array}{c}\text { Degree of } \\
\text { freedom }\end{array}$ & $\begin{array}{c}\text { Asymp. Sig. } \\
(2 \text {-sided })\end{array}$ & $\begin{array}{c}\text { Exact Sig. } \\
(2 \text {-sided })\end{array}$ & $\begin{array}{c}\text { Exact Sig. } \\
(1-\text { sided })\end{array}$ \\
\hline Pearson Chi-Square & $12.625^{\text {a }}$ & 1 & .000 & ---- & ---- \\
\hline Continuity Correction & 11.933 & 1 & .001 & ---- & ---- \\
\hline Likelihood Ratio & 12.771 & 1 & .000 & ---- & .001 \\
\hline Fisher's Exact Test & ---- & ---- & --- & -000 \\
\hline $\begin{array}{c}\text { Linear-by-Linear } \\
\text { Association }\end{array}$ & 12.606 & 1 & .000 & --- \\
\hline N of Valid Cases & 680 & ---- & ---- & ---- & --- \\
\hline $\mathrm{P}<.05 \quad$ & & &
\end{tabular}

The results of Chi-Square tests in table 2 showed a significant relationship between the gender of Ilami EFL teachers and their observing of rules for intonation patterns with the $\mathrm{p}$ value of .001 at the $.05 .(\mathrm{P}<.05)$

Table 4 depicts Cramer's V measure for the variables of Ilami EFL teachers and their observing of the rules for intonation patterns.

Table 4. Symmetric Measures for the gender of Ilami EFL teachers and the rules of intonation

\begin{tabular}{|c|c|c|c|c|c|}
\hline & & Value & $\begin{array}{l}\text { Asymp. Std. } \\
\text { Error }^{\mathrm{a}}\end{array}$ & $\begin{array}{l}\text { Approx. } \\
\mathrm{T}^{\mathrm{b}}\end{array}$ & Approx. Sig. \\
\hline Nominal by & Phi & 0.136 & ---- & ---- & 0.000 \\
\hline Nominal & Cramer's V & $\begin{array}{l}0 . \\
136\end{array}$ & ---- & ---- & 0.000 \\
\hline Interval by Interval & Pearson's R & 0.136 & 0.037 & 3.581 & $0.000^{\mathrm{c}}$ \\
\hline Ordinal by Ordinal & Spearman Correlation & 0.136 & 0.037 & 3.581 & $0.000^{\mathrm{c}}$ \\
\hline $\mathrm{N}$ of Valid Cases & & 680 & ---- & ---- & ---- \\
\hline
\end{tabular}

$\mathrm{V}=.136$

Rutgers (2003) established that when the measure of $\mathrm{V}$ is between (a) 0 to .10, a weak relationship exists between variables; (b) .11 to .29, a moderate relationship exists between variables; and (c) .30 to 1, a strong relationship exists between variables. According to table 4.25 the measures of the association of the relationship as described by Cramer's $\mathrm{V}$ is $\mathrm{V}=.136$ which falls between .11 to .29 indicating a moderate relationship between the variables of the gender of Ilami EFL teachers and their observing of intonation rules. 


\section{Discussions and Conclusion}

The prime goal of the current study was to investigate Ilami EFL teachers' performance in observing 17 general intonational patterns of American English. From among different variables that might affect English pronunciation, a salient one, namely gender was brought into investigation. The existence of relationship between variables of gender and observing intonational patterns was determined. Data were collected through an interview (mainly aimed at asking the participants to read topically unrelated sentences). The researcher adopted Chi- Square test to determine the correlations. The following presents the discussion of the findings.

The gender of Ilami EFL teachers and their observance of intonational patterns showed statistically significant relationship. The test results indicated that male participants observed the patterns of intonation better than female participants. The reason for such finding may be ascribed to the influence of the interviewer and the context. Since the interviewer was a woman whose tendency toward using more standard forms was clear to men, the male interviewee tried to accommodate to the so-called speech of the female interviewer bearing in mind that women try to observe the standard forms. (Holmes 2008).

Another interpretation for the better performance of male participants regarding intonational patterns is probably the sensitivity of men to contextual factors. It means that women were being interviewed by a member of their own gender. In such context it is likely that the interview context would be considerably more comfortable for women than for men. Female solidarity would reduce the formality of the context and as a result the women in the study didn't take the interview as serious as it would be. Perhaps, the results became reverse if the interviewer was a male.

The results also suggests that maybe the female participants in the context of Ilam city are not status-conscious individual who use more standard forms to ensure they are perceived as society statusful. However, the same behavior may be interpreted quite differently by different researchers.

Finally the findings may indicate that the text book material designers/developers in Iran (as an EFL context) have overlooked intonation as a suprasegmental aspect of speech and in fact the reason for marginizing suprasegmental and even segmental phonology in most cases is that in Iran as an EFL context English language is considered as a pass to get higher degrees, and/or promotions not as a means which paves the ways of international communication in every field of science and technology. However, the current study may serve as a useful baseline for comparison with other researches running/run on a larger population.

Furthermore, the findings of this study expand the works of previous researchers in the area of intonation as a suprasegmental aspect of speech. The literature on the effect of gender on observing the intonational patterns suggests a need for an in-depth teaching of intonational patterns as pre-service courses for teachers.

\section{References}

Anderson-Hsieh, J., Riney, T., Kohler, K. (1994). Connected speech modifications in English of Japanese ESL learners. Issues and Developments in English and Applied Linguistics (IDEAL), 7, 31-52.

Averry, P., Ehrlich, S. (1992). Teaching American English Pronunciation. Oxford University Press.

Baily, K.M. (2003). Speaking. In D. Nuan (Ed), Practical English Language Teaching (pp.53-53).New York: McGrawHill.

Brazil, D., Coulthard, M., \& Johns, C. (1980). Discourse Intonation and Language Teaching. London: Longman.

Brend, R. (1975). Male-female intonation patterns in American English. In Thorne, B. Henley, N. (Eds), Language and Sex: Difference and Dominance (pp. 84-87). MA: Newbury House.

Celce-Muricia, M. (2001).Teaching English Pronunciation: A Book of readings. New York: Routledge, Chapman, and Hall.

DeBot, K. \& Mailfert, K. (1982).The Teaching of Intonation: Fundamental research and classroom applicants. TESOL Quarterly, 16,71-77.

Holmes, J. (2008). An Introduction to Sociolinguistics. England, Pearson.

Mennen, I. (2006). Phonetic and phonological influences in non-native intonation: an overview for language teachers. QMUC Speech Science Research Centre Working Paper WP9.

Jahandar et al., (2012). A Gender-based approach to pronunciation accuracy of advanced EFL learners.

Lakoff, T.R. (2004). Language and Women's Place. (Bucholtz, M. (ed), Revised and Expanded Edition). Oxford: Oxford University Press. 39, 78-81.

Laroy, C. (1995). Pronunciation. Oxford University Press.

Nolan, F. (2006). Intonation. The Handbook of English Linguistics, Blackwell Publishing, (chapter 19).

Richards, J.C., et al. (1992). Longman Dictionary of Language Teaching and Applied Linguistics. Longman Group UK Limited.

Rutgers University, Camden. (2003). Table/graph format in interpretation. Retrieved September 15, 2003, from http://Sociology.camden.rutgers.edu/ curriculum/ format.htm.

Yates, L. (2013). Pronunciation in Second Language learning and Teaching Curiculum. Fifth Annual Conference.

Yavas, M. (2006).Applied English Phonology. Blackwell Publishing. 
Appendix I

Intonation

Falling intonation. lexical items and sentential adverbs get the tonic accent if: Verb is intransitive

Rule 1: Lexical items

The bird flew away

Rule 2: Sentential adverbs It wasn't a nice day unfortunately.

Full fall for declarative, and "wh" questions.

Rule 3: Declarative question I'm leaving the house right now

Rule 4: Wh question Which way did you go?

Short fall for a perfunctory attitude by speaker

Rule 5: Whatever you say.

Rising intonation: lack of assurance and indicative of non-finitness and incompletion.

Rule 6: High rise which is indicative of an attitude of puzzlement or unbelieving.

This is a joke?

Low rise

Rule 7: In yes-no questions

Has your uncle left already?

Rule 8: Echo questions

Where will I work? I haven't thought of that yet.

Rule 9: Repetition questions

What are you doing? (I haven't heard you)

Rule 10: Open -choice alternative questions

Would you like coffee or tea?

Rule 11: Tag questions that signal uncertainty

She usually comes at ten, doesn't she?

Rule 12: Items in a list prior to the last

I need to buy a shirt, a jacket, and a tie

Rule 13: Questions that display readiness to present some new information

Falling rising

Rule 14: Agreement with reservation

You can do it that way.

Rising falling

Rule 15: Feeling of approval

You can do that.

Rule 16: Feeling of disapproval or showing sarcastic attitude.

That's wonderful.

Rule 17: Level to show the bored or sarcastic tone.

-He will be at the party? -Great 